\title{
LINKEDIN LEARNING: A VALUABLE RESOURCE FOR CPE CREDITS
}

Jodi Olson

Winona State University $\bullet$ Winona, MN

Joann Segovia

Winona State University • Winona, MN

\section{ABSTRACT}

This article describes the continuing professional education opportunities available for CPAs through LinkedIn Learning training courses. Practitioners will likely find the affordability, ease of use, and breadth of content valuable to them in their practice of public accounting for $\mathrm{CPE}$, while also utilizing the resources for staff development and client services.

Key Words: CPE, LinkedIn Learning, NASBA Registry, QAS Self Study

\section{INTRODUCTION}

CPAs may gain affordable, easily accessible continuing professional education (CPE) credits through LinkedIn Learning, which has recently become a National Association of State Boards of Accountancy (NASBA) approved sponsor for training courses. NASBA provides regulatory guidance, as much as possible, across state boards of accountancy to facilitate uniformity for educational requirements to sit for the CPA exam (Mastracchio, 2008) and compliance with CPE to maintain credentials once an individual becomes licensed (Humphrey, Plunkett \& Herring, 1988). Currently, variation exists among state boards for $\mathrm{CPE}$ rules, but many states require NASBA or other authoritative approval of courses for at least a percentage of their CPAs' continuing education as a benchmark of quality (CPE Requirements, n.d.).

LinkedIn Learning purchased Lynda.com in 2015 which was founded in 1995 as a resource for helping students with academics and professional skills. Trained experts provide video tutorials for online learning. In December 2018, LinkedIn Learning became part of the NASBA Registry (Porter, 2015; NASBA Registry, n.d.). LinkedIn Learning now provides access to 700+ NASBA approved courses to earn CPE credits (linkedinlearning.com). This paper describes this affordable, easy to use resource, with relevant content for CPAs who need to fulfill CPE credits. 


\section{AFFORDABILITY AND EASE OF USE}

LinkedIn Learning provides an unlimited potential for CPE at an affordable price. In addition, the membership allows users to access non-CPE related interests such as training for staff development or client services.

An individual can subscribe to the LinkedIn Learning website either on an individual or organizational basis. Individuals can obtain a one-month free trial with a continuing membership fee of $\$ 29.99$ per-month on a month-to-month basis, or $\$ 19.99$ per month on an annual basis. Governmental or corporate entities should call (844) 587-5735 for a customized quote based on number of employees served.

A subscription includes unlimited use of $15,000+$ courses available in five languages and LinkedIn Learning adds and updates courses weekly (linkedinlearning. com). According to a live chat with a LinkedIn Learning representative, (personal communication, November 17, 2019) the free trial period has no limitations on function, including earning CPE credits and printing certificates. The representative also verified that some libraries have subscriptions to LinkedIn Learning and patrons can access courses using their library card. To earn CPE at a library, patrons create accounts using their library card under the library's subscription and have full access to courses and CPE certificates.

With a username and password, one can access the LinkedIn Learning website from a computer or phone. Then one can search for NASBA approved courses by selecting "NASBA" in a "Continuing Education Units" filter. When considering videos, access the course overview information which clearly identifies NASBA certifications, the CPE credits earned upon completion, and the "field of study" in the content (Figure 1).

\section{Figure 1}

\section{LinkedIn Learning NASBA Approved Course Overview}

\section{Course details}

\section{$53 \mathrm{~m}$ - General - Released: 7/31/2019}

Ethical behavior is critical to the success of your career and your company. But ethics are not always black and white. Many factors can affect how people respond in ethically gray situations, including conflicts of interest, fear of failure, and business pressure. To ensure you have a strong ethical compass, you need to be informed and prepared. In this course, filled with practical examples and live-action scenarios, expert Bob McGannon helps you understand what business ethics are and why they are so important. Learn hou to conduct an ethical self-check, apply ethical standards to your work with stakeholders and coworkers, and report any ethical issues that arise. Bob also describes how to promote ethical behavior from top to bottom and explains how ethics are evolving in rapidly changing world. 


\section{Figure 1}

\section{LinkedIn Learning NASBA Approved Course Overview (continued)}

\section{Learning objectives}

- Recall the fundamentals of applying ethics in business.

- Identify the ethics of a stakeholder in business.

- Determine the most effective ways to learn and adapt when working ethically in business.

- Identify ethical ways to help make team members feel included.

- Define transparency decisions.

Skills covered in this course

Business Ethics

\section{Viewers of this course}

440 members like this course - 11,698 people watched this course

\section{What they do}

Process Specialist - Information Technology Consultant - Business Analyst - Salesperson - Administrative Employee Where they work

DWalmart - Tata Consultancy Services - D Deloitte - E Nokia - o Genpact

\section{CEU - Continuing Education Units (1 certification available)}

National Association of State Boards of Accountancy (NASBA)

Continuing Professional Education Credit (CPE): 1.6

Recommended NASBA Field of Study: Behavioral Ethics

Sponsor Identification number: 140940

To earn CPE credits the learner is expected to:

Complete all videos and chapter quizzes

Score $70 \%$ or higher on final exam

Glossary: see PDF file in the Exercise Files area

Program Level: Basic

Prerequisite Education: There are no prerequisites for this course.

Advanced Preparation: There is no advance preparation required for this course.

If you undertake this course for CPE credits, you can leave final comments in the Self Study Course Evaluation.

Linkedln Learning is registered with the National Association of State Boards of Accountancy (NASBA) as a sponsor of continuing professional education on the National Registry of CPE Sponsors. State boards of accountancy have final authority on the acceptance of individual courses for CPE credit. Complaints

QAS regarding registered sponsors may be submitted to the National Registry of CPE Sponsors through its web site: wwW.nasbaregistry.org

Register here with Linkedln Learning. For course refund policy, issue resolution, and additional info please see the Linkedln User Agreement. For more information regarding administrative policies such as complaint and refund, please contact our offices at $+1650-687-3600$.

Show less

Instructor 
Alternatively, users can access courses through the NASBA Registry course library and filtered base on subject matter (Course Library, n.d.). By choosing the course this way, LinkedIn Learning retrieves the selected course.

For firms wanting to preselect coursework for staff, administrators can develop playlists to share with their staff to assure the user views the desired content. Also, because of LinkedIn Learning's affiliation with LinkedIn, new skills can transfer to individual LinkedIn profiles at the user's discretion.

Upon completion of a course, users can easily download and print CPE Certificates for CPE tracking by answering correctly $70 \%$ of the end of the course quiz questions. The website also tracks earned CPE for its members (linkedinlearning. com). See Figure 2 for an example of a CPE certificate which clearly states relevant course information at the bottom, including field of study, earned CPE credits, and NASBA approval.

Figure 2

LinkedIn Learning CPE Certificate

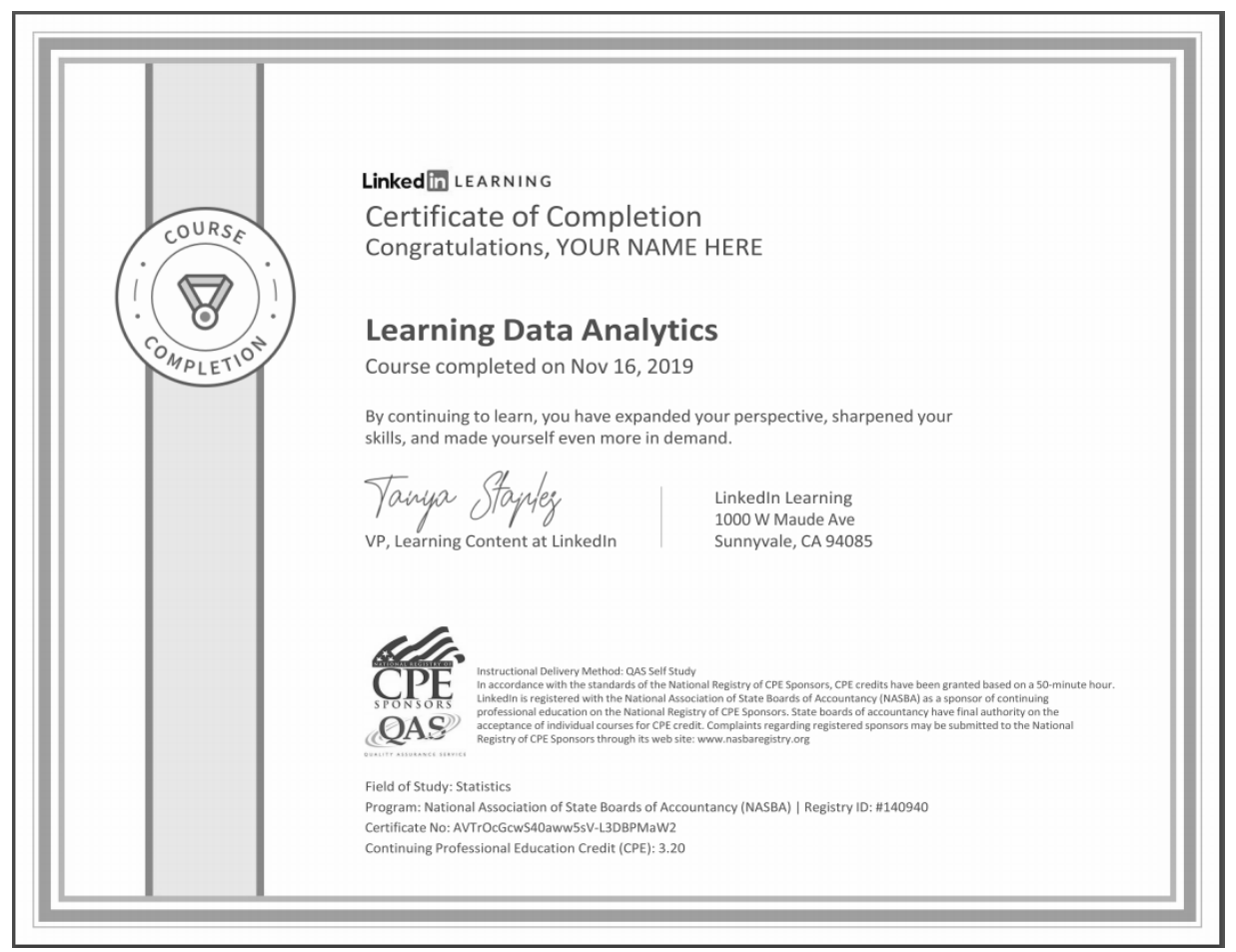




\section{RELEVANT CONTENT}

NASBA and the American Institute of Certified Public Accountants (AICPA) jointly publish "The Statement on Standards for Continuing Professional Education (CPE)", as a framework for state boards to use in regulating CPE requirements. As last updated in December 2019, the statement refers to fields of study as "primary knowledge" needed to practice as a CPA (Statement on Standards, 2019; Fields of Study, 2019). The fields of study are published in a separate report, "Fields of Study That Qualify for Continuing Professional Education," and separates the subjects into thirteen technical and seven non-technical groups (CPE Requirements, n.d.).

Table 1 presents the thirteen technical fields of study with the number of NASBA approved LinkedIn Learning courses available for each. For each field, an example of a LinkedIn Learning course with the related CPE credits available is provided (Course Library, n.d.).

Table 1

NASBA Technical Fields of Study (236 LinkedIn Learning Courses Available)

\begin{tabular}{|l|c|l|c|}
\hline \multicolumn{1}{|c|}{ Field } & $\begin{array}{c}\text { \# of } \\
\text { Available } \\
\text { courses }\end{array}$ & \multicolumn{1}{|c|}{$\begin{array}{c}\text { Example of One Available Course } \\
\text { within the Field }\end{array}$} & $\begin{array}{c}\text { CPE } \\
\text { Hours }\end{array}$ \\
\hline Accounting & 5 & QuickBooks Pro 2019 Essential Training & 7.4 \\
\hline $\begin{array}{l}\text { Accounting } \\
\text { (Governmental) }\end{array}$ & 0 & & \\
\hline Auditing & 1 & Audit and Due Diligence Foundations & 3.8 \\
\hline Auditing (Governmental) & 0 & & 2 \\
\hline Business Law & 4 & Understanding Copyright: A Deeper Dive & 2 \\
\hline Economics & 2 & Excel: Economic Analysis and Data Analytics & 2.4 \\
\hline Finance & 25 & Forecasting Using Financial Statements & 3.4 \\
\hline Information Technology & 108 & Learning C & 5.4 \\
\hline Management Services & 31 & Enterprise Agile: Changing Your Culture & 2.2 \\
\hline Regulatory Ethics & 0 & & 2.6 \\
\hline Specialized Knowledge & 2 & R Programming in Data Science & 2.8 \\
\hline Statistics & 10 & Data Analytics for Business Professionals & \\
\hline Taxes & 0 & & \\
\hline
\end{tabular}

For the seven non-technical fields of study, 186 LinkedIn Learning courses exist. Table 2 presents the non-technical fields of study with 539 available LinkedIn Learning courses (Course Library, n.d.). 
Table 2

\section{NASBA Non-Technical Fields of Study (587 LinkedIn Learning Courses Available)}

\begin{tabular}{|l|c|l|c}
\hline \multicolumn{1}{|c|}{ Field } & $\begin{array}{c}\text { \# of } \\
\text { Available } \\
\text { courses }\end{array}$ & \multicolumn{1}{|c}{$\begin{array}{c}\text { Example of One Available Course } \\
\text { within the Field }\end{array}$} & $\begin{array}{c}\text { CPE } \\
\text { Hours }\end{array}$ \\
\hline Behavioral Ethics & 3 & Project Management Foundations: Ethics & 1.8 \\
\hline $\begin{array}{l}\text { Business Management \& } \\
\text { Organizations }\end{array}$ & 53 & Measuring Business Performance & 2.8 \\
\hline $\begin{array}{l}\text { Communications and } \\
\text { Marketing }\end{array}$ & 124 & Brand \& Marketing Integration & 1.6 \\
\hline $\begin{array}{l}\text { Computer Software \& } \\
\text { Applications }\end{array}$ & 209 & Excel 2019 Essential Training & 4 \\
\hline Personal Development & 109 & Learning to Be Approachable & 1 \\
\hline $\begin{array}{l}\text { Personnel/Human } \\
\text { Resources }\end{array}$ & 59 & Managing Organization Changes for Managers & 2.4 \\
\hline Production & 9 & Lean Inventory Management & 2 \\
\hline
\end{tabular}

As of this writing, non-technical courses far outnumber technical courses, but a sizeable number exist in both categories. Though many state boards do not put requirements on technical versus non-technical fields of study, some do have a minimum level of technical and non-technical CPE credits to be earned for each reporting cycle (CPE Requirements, n.d.).

Practicing CPAs will likely want to have certain technical skills updated, regardless of the rules of their jurisdiction; unfortunately, LinkedIn Learning currently provides a limited number of courses in the accounting, auditing, and tax fields of study. However, given that most states require an average of 40 hours every year of CPE, LinkedIn Learning's content can provide some of the required hours.

Many states require a minimum number of ethics hours per reporting period. Tables 1 and 2 show limited courses in the Regulatory Ethics and Behavioral Ethics fields of study, yet a search for NASBA specific "ethics" courses within LinkedIn Learning will yield many more results. LinkedIn Learning labels these additional courses as other fields of study such as Business Management \& Organization or Personal Development.

In addition to NASBA approved LinkedIn Learning courses, some state boards do allow self-study courses not on the NASBA registry and users could use LinkedIn Learning courses for these additional credits. For example, the Lease course shown in Figure 3 did not have NASBA approval in the "accounting" technical area as 
of November, 2019, but now approval has been granted. A state board may have allowed the content for CPE back in 2019 before NASBA approval, since GAAP recently had changed accounting for leases and one of the instructors, a Professor of Accounting at Brigham Young University, had just developed the course (October $31,2019)$. The topic seems quite relevant to those having leeway to take CPE courses outside of the NASBA registry and would have qualified back in 2019.

\title{
Figure 3
}

\section{Accounting Foundations: Leases (LinkedIn Learning Course)}

\section{Course details}

1h $43 \mathrm{~m}$ - Intermediate - Released: 10/31/2019

Explore how accountants handle leases and the corresponding assets and liabilities, and learn about the impact of the 2019 Financial Accounting Standards Board (FASB) lease rules, Instructors Jim and Earl Kay Stice give an overview of leasing versus buying, and discuss different ways to finance assets before giving a quick history of lease accounting and the FASB financial standards. They then cover how the 2019 FASB rules affect the way organizations account for leases, and address transition difficulties.

\section{Learning objectives}

- Calculate the least expensive financing method in a given situation.

- Explain how leasing options improve relationships between a business and customer.

- Recognize an example of substance over form that would require the lease to be shown as a sale on a balance sheet.

- Summarize the importance of keeping lease payments below the FASB value of payments threshold.

- Determine the effect of an adjusted asset turnover ratio on a company's efficiency.

- Identify Sir David Tweedie's view on operating leases.

- Recall the major accounting rule change adopted by the FASB and the IASB in 2016.

- Explain how to calculate the annual depreciation expense under the new accounting rule that will classify the lease as a financing lease.

Skills covered in this course

\section{Lease Financing Lease Administration}

\section{Viewers of this course}

164 members like this course $\cdot 4,367$ people watched this course

\author{
What they do \\ Corporate Finance Specialist - Finance Specialist - Accountant
}

Where they work

- IBM - > Accenture

*7 Walmart - Amazon - $6 \mathrm{EY}$ 
Figure 3

\section{Accounting Foundations: Leases (LinkedIn Learning Course), (continued)}

Viewers of this course

164 members like this course $\cdot 4,367$ people watched this course

What they do

Corporate Finance Specialist - Finance Specialist - Accountant

Where they work

DIBM - > Accenture - 2 Walmart - Amazon - G EY

\section{CEU - Continuing Education Units (1 certification available) \\ National Association of State Boards of Accountancy (NASBA) \\ Continuing Professional Education Credit (CPE): 3 \\ Recommended NASBA Field of Study: Accounting \\ Show more $\checkmark$}

\section{Instructors}

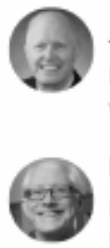

Jim Stice

Professor of Accounting at BYU

View on Linkedln

Kay Stice

Earl Kay Stice is the PricewaterhouseCoopers Professor of Accounting at the BYU Marriott School of

Management.

View on Linkedln

\section{METHOD OF DELIVERY}

LinkedIn Learning marks all NASBA approved LinkedIn Learning courses as "Quality Assurance Service (QAS) Self Study". NASBA developed this standard to assess the value of self-study courses. Each NASBA approved course goes through an in-depth instructional design review to determine if the course meets the standards required for listing on the NASBA Registry (QAS Self Study, n.d.)

Some state boards also put restrictions on self-study courses. They may limit the number of CPE credits to one-half of the number of hours needed in a reporting cycle while some jurisdictions allow 100\% of a CPA's CPE from a selfstudy delivery method. 


\section{CLIENT SERVICE OPPORTUNITY}

CPAs can better serve their clients with knowledge of LinkedIn Learning training opportunities. Clients may have professional staff that could use CPE credits for their area of expertise. LinkedIn Learning offers approved CPE credit hours to earn or maintain credentials in project management, human resources, and business analysis. Also, CPAs can direct clients needing help with a certain software application to LinkedIn Learning for help with Microsoft products such as Excel or Access, or small business accounting software such as QuickBooks or Sage, or data analytics platforms such as Tableau. Clients can also obtain CPAs' recommendations for other learning opportunities such as help with determining which software or hardware to select or increasing soft skills needed for potential staffing issues or cultural challenges through LinkedIn. These recommendations from CPAs could provide a valuable service to clients and save the CPA time.

\section{CONCLUSION}

Since state boards of accountancy review and approve CPE, one needs to understand their state's requirements. However, the inclusion of LinkedIn Learning as a sponsor in the NASBA Registry sends a clear message to the profession that these video tutorials can provide affordable, easily accessible CPE with a breadth of content. Furthermore, given the free trial period and free access with a library card at a public library, the opportunity to assess this as a viable option for CPE credits comes at no risk to the practitioner. Therefore, it is recommended that accounting practitioners consider LinkedIn Learning for CPE, staff development, and client service.

\section{REFERENCES}

Course Library. (n.d.). Retrieved June 16, 2020, from NASBA Registry website: https://www.nasbaregistry.org/course-library?\&searchTerm=linkedin $\% 20$ learning \&categories $=8$ ACB 7344-5056-B733-4906A B68945AAA 39\&searchgroup $=00000001$-course-library

CPE Requirements. (n.d.). Retrieved June 16, 2020, from NASBA website: https:// www.nasbaregistry.org/cpe-requirements

Fields of Study. (2019, December). Retrieved July 28, 2020, from NASBA

Registry website: https://www.nasbaregistry.org/_ media/Documents/2019standards-and-fos/Fields-of-Study-Document---December-2019.pdf

Humphries, F.A., Plunkett, L. M., \& Herring, R. B. (1988). Let's Make Required CPE Rules Uniform. Journal of Accountancy, 166(6), 70-74. 
NASBA Registry. (n.d.). National Registry for CPE Sponsors. Retrieved June 16,2020 from NASBA Registry website: https://www.nasbaregistry.orgsponsorlist?\&azletter $=$ L\&searchgroup $=2099 \mathrm{EC} 2 \mathrm{E}-$ exhibitors

Mastracchio Jr., N. J. (2008). The Role of NASBA and State Boards in Accounting Education. CPA Journal, 78(3), 64-69.

Porter, J. (2015, April 27). From Near Failure To A \$1.5 Billion Sale: The Epic Story of Lynda.com. Retrieved June 16, 2020, from https://www. fastcompanycom/3045404/from-near-failure-to-a-15-billion-sale-the-epicstory-of-lyndacom

QAS Self Study. (n.d.). Retrieved June 16, 2020 from https://www.nasbaregistryorg/ preparing-to-apply/qas-self-study

Russel, M. (2018, December 3). CPAs - Earn Your Continuing Professional Education (CPE) Units Anytime, Anywhere on LinkedIn Learning. Retrieved June16, 2020, from https://learning.linkedin.com/blog/whats-new/cpas-_earnyour continuing-professional-education--cpe--units-a

Statement on Standards. (2019, December). The Statement on Standards for Continuing Professional Education (CPE). Retrieved June 16, 2020, from NASBARegistry website: https://www.nasbaregistry.org/_media/Documents/ 2019-standards-and-fos/Statement_on_Standards_for_CPE_ProgramsDecember-2019.pdf. Accessed 16 June 2020.

\section{BIOGRAPHICAL SKETCH OF AUTHORS}

Jodi Olson is an Assistant Accounting Professor at Winona State University. She has a Doctorate in Business Administration from Metropolitan State University. She is a CPA and a CMA. Her research interests focus on accounting education.

Joann Segovia, CPA, Professor at Winona State University, obtained her doctorate degree at Texas Tech. Her research interests focus on accounting education and accounting information systems. 
